\title{
Perceived Effects of Climate Variability on Cassava Production among Small Scale Farmers in Anambra State, Nigeria
}

\author{
Samuel E. Anarah (Corresponding Author) \\ Department of Agricultural Economics \& Extension, Nnamdi Azikiwe University Awka, \\ Anambra State, Nigeria, E-mail: se.anarah@unizik.edu.ng \\ Caleb I. Ezeano \\ Department of Agricultural Economics \& Extension, Nnamdi Azikiwe University Awka, \\ Anambra State, Nigeria, E-mail: ci.ezeano@unizik.edu.ng \\ Ogonna O. Osuafor \\ Department of Agricultural Economics \& Extension, Nnamdi Azikiwe University Awka, \\ Anambra State, Nigeria, E-mail: oo.osuafor@unizik.edu.ng
}

Received: Sep. 13, 2018

doi:10.5296/jas.v7i2.14758
Accepted: May 4, 2019

Published: May 7, 2019

URL: https://doi.org/10.5296/jas.v7i2.14758

\begin{abstract}
Climate variability is one of the predominant themes in agricultural research. Climate variations can seriously affect agricultural production. It brings about changes in weather patterns which in turn give rise to imbalances in seasonal cycles, harm to ecosystems and water supply affecting agriculture and food production. Extreme weather events such as floods, landslides and drought are caused by climate variation. Studies have shown that root crops such as cassava are most vulnerable to the impact of climate variability. This paper therefore investigated the perceived effects of climate variability on cassava production among small scale farmers in Anambra State. Specifically, the study described the socioeconomic characteristics of small scale cassava farmers in the state; identified the activities of small scale cassava farmers that contribute to climate variability; and ascertained the perception and levels of awareness of climate variability by small scale cassava farmers in the study area. A multi-stage sampling technique was used in selecting the sample units for the study. The instrument for data collection was a well-structured questionnaire based on the objectives. Descriptive statistics was used to actualize the objectives while the hypothesis was tested using multiple linear regression model. The result of the socioeconomic variables showed that majority of the small-scale cassava farmers were within the age range of 41-50
\end{abstract}


years; majority $(59.38 \%)$ of the respondents were females; majority $(32.03 \%)$ have 7 to 11 years of farming experience; majority of the respondents $(35.94 \%)$ have farm size of 0.1 to 0.5 hectares; majority of the farmers $(42.19 \%)$ belong to 3 to 4 farming organizations; majority of the farmers (42.19\%) make income of $\$ 50,000$ to $\$ 100,000$; and majority of the farmers $(53.13 \%)$ produce yield of 3000 to $4000 \mathrm{~kg}$ of cassava. Result of the activities of small scale cassava farmers that contribute to climate variability show that majority of the farmers $(88.28 \%)$ perceived that bush burning contribute to climate variability while $(82.03 \%),(60.16 \%),(56.25 \%)$ and $(50.78 \%)$ indicated that intensive agricultural land use, use of inorganic fertilizers, use of fossil fuels and deforestation contribute also to climate variability, respectively. Based on the perception and level of awareness of climate variability by small scale cassava farmers in the study area, the result show that the farmers were significantly aware of the following climate variability; early onset of rainfall and early cessation; decreased rainfall days; shorter than normal rainfall; absence of frost; low intensity rainfall; flash flooding; unusual patterns of precipitation and high sunshine intensity. It was also found that significant relationship exists between socio-economic characteristics and production level by the small scale cassava farmers. Recommendations were made based on the findings.

Keywords: climate variability, cassava production, perceived effects

\section{Introduction}

Climate change is any variation in climate over a period of time as a result of anthropogenic activities or natural variability or both working synergically to constitute serious environmental threat to the earth planet (Ezeano \& Albert, 2012). Climate change is critically affecting agricultural productivity and food security in developed and developing economies of the world. Developing countries like Nigeria often depend on rainwater for crop production (Elijah, et al., 2018). Until recently, the effects of man's activities on climate variations were perceived as negligible and so climate change was generally taken for granted (Iheke, \& Oliver-Abali, 2011). However, it is palpably established that climate change is no longer a trivial issue; it is a reality that is seriously affecting the earth already, especially challenging agricultural productivity and food security in both developed and developing economies of the world and thus requires urgent attention (Elijah, et al., 2018). Climate change/variations can seriously affect agricultural production. It brings about changes in weather patterns which in turn give rise to imbalances in seasonal cycles, harm to ecosystems and water supply affecting agriculture and food production, causing sea levels to rise. Extreme weather events such as floods, landslides and drought are caused by climate change/variation (Agbugba \& Elijah, 2017).

Considering the significance of cassava as most produced staple food in Nigeria, and due to its high reliability on climate variables, concern has been expressed over the years by individuals, institutes, agencies and government at both local and international levels regarding the potential effects of climate variability on its productivity. This has also motivated lots of research work on climate variability and agriculture over the past decade (Apata, et al., 2009; Ohajianya \& Osuji, 2012). The United Nations Framework Convention 
on Climate Change (UNFCCC, 2017), sees climate variability as a global environmental change likely to have a serious effect on natural and human systems, economies and infrastructures. Though Africa is understood to be a marginal contributor to the causes of this global variability in climate, it is believed to suffer more due to its low adaptive capacity. Moreover, the nature of these biophysical effects and the human responses to these changes are complex and uncertain, as these changes keep manifesting in different forms yearly and they are already having a strong impact on Nigeria particularly in the areas of food security, land use, energy, biodiversity, health and water resources. This is so, because Nigeria, like all other countries of Sub-Saharan Africa, is highly vulnerable to the impacts of climate variability due to her poor adaptive capacity (Ohajianya \& Osuji, 2012).

According to Nigeria Meteorological Services (NIMET, 2007) and Central Bank of Nigeria (CBN) Statistical Data (2008), the average minimum and maximum temperatures have been increasing by about $0.25^{\circ} \mathrm{C}$ and $0.15^{\circ} \mathrm{C}$, respectively, over the past decade and volume of rainfall has been changing since the past 30 years and is expected to continue in the future. These changes, as evidenced by the continuous change in earth's temperature, precipitation levels and hydrologic balances, have led to droughts, flooding, desertification and disease/pest outbreaks, affecting the weather dependent agricultural systems in recent time and making the region highly vulnerable to the vicissitude of climate system and more food insecure. This vulnerability is being felt in large measure due to weak institutional capacity and limited engagement in environmental and adaptation issues. Although this variability in climate existed right from pre-modal time, it had little or no effect on the nation's agricultural productivity during the pre-independent era when agriculture was the bedrock of the nation's development.

\section{Statement of the Problem}

Majority of cassava farmers in the country are small scale farmers who depend on rain-fed agricultural system. Unfortunately, in recent times the weather/climate predictions have failed, thereby, misleading the farmers and causing disasters. This has often led to decrease in their agricultural production, as this phenomenon (climate variability) has eroded hard-won gains and seriously undermining prospects for development even with the efforts being put in by government, researchers, donor agencies, institutions, agencies and international organizations (Ogbo \& Onyedinma, 2012). Climate, which is the primary determinant of agricultural production, has often changed throughout earth's history; there is no doubt that the variability continues even in the future (Ezeano, 2016). Anyadike's (2009) study showed that the recent global warming has influenced agricultural productivity negatively in Sub-Saharan Africa, mostly Nigeria, leading to decline in food production in the nation. A lots of these variability are believed to be man induced through industrialization and agricultural activities such as deforestation, bush burning, use of inorganic fertilizers, intensive livestock farming system and storage of wastes in landfills which in turn releases lots of greenhouse gases to the environment (Ezeano, et al., 2016). Also, recent estimates suggest that the absence of creating high level of awareness to these variabilities in climate, would result in a loss of between $2 \%$ and $11 \%$ of Nigeria's GDP by 2020 and rising above this to the range of $12-50 \%$ by 2050 , thereby, compromising the attainment of the Millennium 
Development Goals of 2015 (BNRCC, 2011).

Studies such as: Elijah, et al., (2018); Mbah, et al., (2016); Nwaiwu (2014) and some others have focused on the impacts and effects of climate change on different crops. Also, many other related studies on climate variability and agriculture have focused mostly on developed countries while only very little research has focused on the tropical rainforest zones of the developing regions like Nigeria who are most vulnerable to climate variability menace. It therefore, becomes pertinent to know the perception of small scale farmers regarding the effects of climate variability on cassava production. This suggests a very wide and invaluable knowledge gap; hence the study aimed at perceived effect of climate variability on cassava production among small scale farmers in Anambra state.

\section{Objectives of the Study}

The broad objective of this study was to determine the perceived effects of climate variability on cassava production among small scale farmers in Anambra State. The specific objectives were to:

i. describe the socioeconomic characteristics of small scale cassava farmers in the state;

ii. identify the perceived activities of small scale cassava farmers that contribute to climate variability;

iii. ascertain the levels of awareness of climate variability by small scale cassava farmers in the study area.

\section{Hypothesis}

There is no significant relationship between socioeconomic characteristics and production level of small scale cassava farmers.

\section{Significance of the Study}

The findings will provide relevant information to agricultural planners in their policy formulation relating to effects of climate variability. The results of this study are expected to give direction to policies to increase agricultural productivity, and mitigating effects of climate variability on cassava production in Anambra State. Researchers are going to have a good data base to look at climate variability for further work.

\section{Review of Related Literature}

\section{Farmers' Activities that Contribute to Climate Variability}

The phenomenon of climate variability is linked to both natural and anthropogenic (human) causes. According to (Nzeh and Eboh, 2010), there are many prevailing factors in Nigeria that are likely to contribute to climate change. The causes of climate change can be broadly classified into two major types, namely natural causes and human activities. Climate change is a natural process but recent trends related to climate change are alarming mainly due to anthropogenic reasons (Khanal, 2009). Agriculture is an important contributor of greenhouse gas emissions at the global scale. According to World Bank (2008), agriculture contributes 
about half of the global emissions of two of the most potent non-carbon dioxide greenhouse gases: nitrous oxide and methane. FAO (2008) reported that agriculture contributes over $20 \%$ of global anthropogenic greenhouse gas emissions. The on-going build-up of greenhouse gases in the atmosphere is prompting shifts in climate across the globe that is already affecting agro-ecology and growing conditions. Practices, such as application of fertilizers, rearing of livestock and related land clearing and burning are some agricultural activities that influence both levels of greenhouse gases in the atmosphere and the potential for carbon storage and sequestration (Ezeano, et al., 2016).

The report of World Bank (2008) also showed that the use of livestock manure, nitrogenous fertilizers and irrigated paddy. Burning of biomass, ruminant's centric fermentation and animal waste treatment are responsible for producing most agricultural nitrous oxide and methane emissions. International Federation of Organic Agriculture Movement (IFOAM) (2007) highlighted that conventional agricultural activities of farmers contribute to climate change because it:

i. uses synthetic fertilizers and pesticides that require significant amount of energy to manufacture;

ii. applies excessive amounts of nitrogen fertilizer that are released as nitrous oxide;

iii. operates intensive livestock holdings that overproduce manure and methane;

iv. relies on external soy-based animal feeds that require the burning of huge amount of fuel that releases carbon-monoxide to the atmosphere creating climatic problems; and

v. mines the earth of the nutrients needed to sustain production; thereby leading to the clearing of rainforest with slash and burn techniques, that reduce carbon storage and release huge amounts of carbon dioxide from burning vegetation.

As a result, it is of interest to stakeholders in the agricultural sector to understand the kinds of impact their agricultural activities will have on sustainable food and crop production due to effect of climate change (Ezeano, et al., 2016).

\section{Empirical Framework}

Mbah, et al., (2016) studied the analysis of climate change effects among rice farmers in Benue State, Nigeria. The study was carried out in Benue state; data collected from 90 respondents were analyzed using frequent distribution, percentage, mean score and standard deviation. Findings of the study revealed that majority of the farmers were males. Major perceived causes of climate change were; use of generator which produce fumes, continuous cropping, human activities (tillage), use of inorganic manure, burning of fire wood, bush burning, deforestation, increase in population which leads to lose of farmland land degradation due to soul erosion over grazing of farm land by life stocks and burning of fossil fuel by industries and automobile, among others. Results also indicate that unemployment desertification, loss of farm land to flood and erosion, increase vulnerability to soil erosion, increase in pests and diseases infestation in rice farm, increase in growth of weeds, easy loss 
of water from the soil, reduce soil fertility, causes stunted growth of weed, easy loss of water from the soil, reduce soil fertility causes stunted growth in rice crops, among other were perceived effects of climate change in rice production. Human activities such as deforestation, overgrazing of farm land by livestock, use of inorganic manure, etc. should be discouraged in order to cushion the effects of climate change as well as increasing productivity among rice farmers.

Okeke, et al., (2016) jointly studied the effect of rising temperature and wind on productivity of women farmers in Anambra East local government of Anambra state Nigeria. The study was an investigation into the effect of climate change on productivity of women farmers in Anambra East local government Area of Anambra state. Data were collected from 30 respondents. Data were analyzed using descriptive statistics. The results of the study showed that majority of the respondents were young. Rising temperature played a vital role in agricultural productivity such as reduction of grain formation when it coincided with hot season. The erratic wind was observed to have caused several crops removal on the removal of livestock buildings. The conclusion was that adequate winds breaks such as mud/clay house for livestock building should be encouraged and effective capacity building should be developed for the provision and circulation of vital information and knowledge on climate change among the farmers in order to enhance productivity thereby improving the standard of living of the farmers.

Nwaobiala and Nwosu (2014), studied the effect of climate change on cassava farmers output in Cross River state, Nigeria. A multistage random sampling technique was used in the selection, 120 respondents were selected. Data on the three important climate variables required for cassava, growth temperature, rainfall and relative humidity were obtained from Cross River state meteorological stations Calabar, Nigeria. The result showed that some of the problems encountered by cassava farmers in coping with the effects on climate change were; lack of frequent training on climate change pestilence, non-access to meteorological data and unavailability of improved cassava varieties. The study recommends regular training on climate change, accessibility of meteorological data and timely availability of improved cassava varieties for farmers for increased cassava production.

\section{Methodology}

This study was carried out in Anambra State. The state is made up of 21 local governments. The state is divided into four agricultural Zones namely: Aguata, Awka, Anambra and Onitsha. The state has a population of 4,182,032 persons distributed as 2,174,641 million males and 2,007,391 million females and covers a land area of about 4,887 sq km (National Population Commission, 2006). Cassava-based and yam-based mixed cropping enterprises dominate small-scale farm holdings in the state (Onubuogu \& Esiobu, 2014).

Multi-stage sampling procedure was used in selecting the sample units for the study. First, one extension block was randomly selected from each of the four Agricultural Zones to avoid bias; Awka North, Orumba North, Oyi and Idemili to give a total of four blocks. Secondly, two circles were randomly selected from each of the four blocks again to give equal coverage. The selected circles were Amansi and Awbaofe nmiri from Awka North, Ufuma and Ajali 


\section{Macrothink}

Journal of Agricultural Studies

ISSN 2166-0379

2019, Vol. 7, No. 2

from Orumba North, Nteje and Umunya from Oyi; and Nkpor and Obosi from Idemili North, thereby giving a total of eight circles. In the third stage, two sub-circles were randomly selected from each of the circles, the selected sub-circles were Ore, Egbeagu, Umueze and Enugu agu from Amansi and Awbaofenmiri, Umuonyiba, Umuogem, Umuabiama and Umuereh from Ufuma and Ajali, Umuefi, Achalla, Umuebo and Amaezike from Nteje and Umunya, Akuzor, Nbuba, Ire and Umuota from Nkpor and Obosi, thereby given a total of sixteen sub-circles. The last stage involved random selection of eight farmers contact from each sub-circles. In all, a total of 128 farmers (respondents) were chosen from a list comprising of 2,270 small-scale cassava farmers provided by Anambra ADP which formed the sampling size.

Primary data was used for the analysis. The primary data were collected with the aid of detailed and well-structured questionnaire administered to the selected cassava farmers and was complemented by scheduled interview. The questionnaire was designed to capture information based on the objectives. Descriptive statistics such as mean, frequency distribution and percentage was used to actualize the objectives, while the hypothesis was tested using multiple linear regressions model.

\section{Model Specification}

The multiple regression model was specified as:

$$
Y_{0}=\beta_{0}+\beta_{1} X_{1 i}+\beta_{2} X_{2 i}+\ldots+\beta_{10} X_{10 i}+e_{i}
$$

Explicitly;

$$
\begin{aligned}
& \beta_{0}=\text { the intercept } \\
& \beta_{1}=\text { slope (regression coefficient) } \\
& Y_{0}=\text { dependent variable } \\
& e_{i}=\text { stochastic term } \\
& X i=\text { independent variables } \\
& Y=\text { yield }
\end{aligned}
$$

Where:

$\mathrm{X}_{1=}$ Age (years)

$\mathrm{X}_{2}=\mathrm{Sex}$

$\mathrm{X}_{3=}$ House hold size (No) 
$\mathrm{X}_{4}=$ Educational level (No of years)

$\mathrm{X}_{5=}$ Farming years (No)

$\mathrm{X}_{6=}$ Farming size $(\mathrm{No})$

$\mathrm{X}_{7=}$ Labour (Man day)

$\mathrm{X}_{8=}$ Membership organization (No)

$\mathrm{X}_{9=}$ Income $(\mathrm{N})$

$X_{10}=\quad$ Yield $(\mathrm{kg})$

\section{Results and Discussion}

\section{Socio-Economic Characteristics of the Farmers}

The socio-economic characteristics of small scale cassava farmers in Anambra State are shown in two Tables (1a and $1 \mathrm{~b}$ ) for better understanding.

Table 1a. Distribution of the socio-economic characteristics of small scale cassava farmers

\begin{tabular}{|c|c|c|c|}
\hline $\begin{array}{l}\text { Socio-economic } \\
\text { Variables }\end{array}$ & $\begin{array}{l}\text { Frequency* } \\
(n=128)\end{array}$ & $\begin{array}{r}\text { Percentage } \\
(\%)\end{array}$ & Mean / Mode \\
\hline \multicolumn{4}{|l|}{ AGE } \\
\hline $20-30 \mathrm{yrs}$ & 15 & 11.72 & 41.25 \\
\hline $31-40 \mathrm{yrs}$ & 32 & 25.00 & \\
\hline $41-50 \mathrm{yrs}$ & 49 & 38.28 & \\
\hline $51-60 y r s$ & 24 & 18.75 & \\
\hline $61 \mathrm{yrs} \&$ above & 8 & 6.25 & \\
\hline \multicolumn{4}{|l|}{ SEX } \\
\hline Male & 52 & 40.63 & 59.38 \\
\hline Female & 76 & 59.38 & \\
\hline \multicolumn{4}{|c|}{ MARITAL STATUS } \\
\hline Single & 27 & 21.09 & \\
\hline Married & 63 & 49.22 & 49.22 \\
\hline Divorced & 8 & 6.25 & \\
\hline Widowed & 30 & 23.44 & \\
\hline \multicolumn{4}{|c|}{ HOUSEHOLD SIZE } \\
\hline $1-2$ & 36 & 28.13 & 3.667 \\
\hline $3-4$ & 54 & 42.19 & \\
\hline $5-6$ & 25 & 19.53 & \\
\hline $7 \&$ above & 13 & 10.16 & \\
\hline \multicolumn{4}{|c|}{ EDUCATIONAL LEVEL } \\
\hline Non-formal & 51 & 39.84 & \\
\hline Primary & 35 & 27.34 & 39.84 \\
\hline Secondary & 28 & 21.88 & \\
\hline Tertiary & 14 & 10.94 & \\
\hline \multicolumn{4}{|c|}{ YEARS OF FARMING } \\
\hline $2-6$ yrs & 30 & 23.44 & 9.167 \\
\hline $7-11$ yrs & 41 & 32.03 & \\
\hline $12-16$ yrs & 36 & 28.13 & \\
\hline 17 yrs\& above & 21 & 16.41 & \\
\hline \multicolumn{4}{|l|}{ SIZE OF FARM } \\
\hline $0.1-0.5 \mathrm{ha}$ & 46 & 35.94 & 5.167 \\
\hline $0.6-1.0 \mathrm{ha}$ & 41 & 32.03 & \\
\hline $1.1-1.5$ ha & 23 & 17.97 & \\
\hline 1.6 ha $\&$ above & 18 & 14.06 & \\
\hline
\end{tabular}


Source: Field Survey, 2017

Table 1b. Distribution of the socio-economic characteristics of small scale cassava farmers

\begin{tabular}{|c|c|c|c|}
\hline $\begin{array}{l}\text { Socio-economic } \\
\text { Variables }\end{array}$ & $\begin{array}{l}\text { Frequency } \\
(n=128)\end{array}$ & $\begin{array}{r}\text { Percentage } \\
(\%)\end{array}$ & Mean / Mode \\
\hline \multicolumn{4}{|l|}{ Sources of labour } \\
\hline Family & 24 & 18.75 & 53.13 \\
\hline Individual & 68 & 53.13 & \\
\hline Hired & 29 & 22.66 & \\
\hline Others & 7 & 5.47 & \\
\hline \multicolumn{4}{|l|}{ Membership of } \\
\hline Organization & 36 & 28.13 & 3.667 \\
\hline $1-2^{\circ}$ & 54 & 42.19 & \\
\hline $3-4$ & 25 & 19.53 & \\
\hline $5-6$ & 13 & 10.16 & \\
\hline \multicolumn{4}{|l|}{7 \& above } \\
\hline \multicolumn{4}{|l|}{ Income } \\
\hline N50,000- $¥ 100,000$ & 54 & 42.19 & 158333.8 \\
\hline ¥100,001- 200,000 & 36 & 28.13 & \\
\hline 丹200,001- 300,000 & 25 & 19.53 & \\
\hline 丹300,001 \& above & 13 & 10.16 & \\
\hline \multicolumn{4}{|l|}{ Yield (kg/ha) } \\
\hline $1,000-2,999 \mathrm{~kg}$ & 29 & 22.66 & 3999.7 \\
\hline $3,000-4,999 \mathrm{~kg}$ & 68 & 53.13 & \\
\hline $5,000-6,999 \mathrm{~kg}$ & 24 & 18.75 & \\
\hline $7,000 \mathrm{~kg} \&$ above & 7 & 5.47 & \\
\hline
\end{tabular}

Source: Field survey, 2017.

The socio-economic variables of Table 1a include age, sex, marital status, household size, educational level and years of farming and size of farm.

Age: Result revealed that the majority of the respondents $(38.28 \%)$ were within the ages 41 and 50 years, few (25\%), were within the ages 31 and 40 years. However, very few $(6.25 \%)$ were 61 years and above. The average age of the farmers was 41.25 . This result tells that the cassava farmers were young and in there active age. This finding is in agreement with Brussel (2009), who observed that farmers within 40 and 50years are productive.

Sex: The result showed that the majority of the small scale cassava farmers $(59.38 \%)$ were females, while $40.63 \%$ were males. The indication is that females were the major cassava farmers in Anambra State. The study of Ibekwe, et al., (2012) revealed that in south east females are the major cassava farmers.

Marital status: The result tells that the majority of the small scale cassava farmers $(49.22 \%)$ were married. This is followed by less than half of farmers who were widowed $(23.44 \%)$, farmers who were single $(21.09 \%)$ and $6.25 \%$ for farmers who are divorced. The high percentage of married people in cassava production indicates that more hands are available for labour involved in small scale cassava production in Anambra State. The study of Ibekwe et al. (2012) also showed that in Imo State married people are more involved in cassava production.

Household size: The result tells that the majority of the small scale cassava farmers $(42.19 \%)$ have family size of 3 to 4 members, $(28.13 \%)$ of the farmers have family size of 1 to 2 , 
(19.53) \% have family size 5 to 6 while $(10.16 \%)$ of the farmers have family size of $7 \&$ above members. The average family size is 3.667 , implying that most of the small scale cassava farmers have a moderately small family size which cannot supply enough labour for cassava production. This finding is in agreement with Nwajiuba, (2010) findings who observed that in Imo State family size of 4 to 5 is relatively small for small scale cassava farmers.

Educational level: The result indicates that (39.84\%) of the small scale cassava farmers have non-formal education; few $(27.34 \%)$ have primary education, very few $(21.88 \%)$ have secondary education while only $(10.94 \%)$ have tertiary education. The implication of this is that the small scale cassava farmers have non-formal education. This finding agrees with Odjugo (2010) who showed that the majority of the rural farmers have non-formal education.

Years of farming: The result indicates that $(32.03 \%)$ of the small scale cassava farmers have 7 to 11 years of farming experience $(28.13 \%)$ have 12 to 16 years of experience, few $(23.44 \%)$ have 2 to 6 years of experience while very few (16.41\%) have 17 years and above of farming experience. The average farming experience is 9.167 years, implying that the cassava farmers are well experienced in cassava production. This result agrees with the finding of Nwajiuba, (2010) who observed that most of the experienced farmers tend to invest their resources and income towards increasing their production.

Size of farm: The result showed that majority of the respondents $(35.94 \%)$ have farm size of 0.1 to 0.5 hectares, few $(32.03 \%)$ have farm size of 0.6 to 1.0 hectares, very few $(17.97 \%)$ have farm size of 1.1 to 1.5 hectares while $14.06 \%$ have farm size of 1.6 hectares and above. The average farm size in the study area was 5.167. This implies that small scale cassava farmer have the tendency for increased cassava production when land is not a constraint to them. This finding reflects land as a useful resource in agricultural production such as cassava (Nzeh and Eboh, 2010).

The socio-economic variables shown in Table $1 \mathrm{~b}$ are sources of labour, membership of organization, income and yield these are discussed as follows;

Sources of labour: Result tells that the majority $(53.13 \%)$ of the farmers use individual labour, few (22.66\%) use hired labour, very few (18.75\%) use family labour while $(5.47 \%)$ of the farmers use other sources of labour. The implication is that small scale cassava farmers prefer individual labour. This finding agrees with the study of Nwajiuba, (2010) who observed that most rural farmers uses individual labour.

Membership of organization: The result showed that majority of the farmers $(42.19 \%)$ belong to 3 to 4 farming organizations, $(28.13 \%)$ belong to 1 to $2,(19.53 \%)$ belong to 5 to 6 while $(10.16 \%)$ belong to 7 and above farming organizations. This implies that membership of organization will give them the advantage of acquiring aid and modern information on effects of climate variability and adaptation from both governmental and non-governmental agencies. This finding agrees with the study of Ezeano (2012), who observed that farmers in organizations tend to disseminate information to their follow farmers.

Income: The result showed that majority of the farmers $(42.19 \%)$ make income of 
$\$ 50,000$ to $¥ 100,000 ; 28.13 \%$ make $¥ 100,001$ to $¥ 200,000$; (19.53\%) make $\$ 200,001$ to $\$ 300,000$ while $(10.16 \%)$ make above $\$ 300,000$. The implication is that small scale cassava farmers make an income of 158333.8. This finding agrees with the study of Nwajiuba, (2010) who observed that rural farmers need government support programme to beef up their income.

Yield: The result showed that the majority of the small scale cassava farmers $(53.13 \%)$ produce yield of 3000 to $4000 \mathrm{~kg}$ of cassava, few $(22.66 \%)$ produce 1000 to $2999 \mathrm{~kg}$, very few $(18.75 \%)$ produce 5000 to $6999 \mathrm{~kg}$ while $(5.47 \%)$ produce $7000 \mathrm{~kg}$ and above. The average yield of the small scale cassava farmers is 3999.7 this implies that small scale cassava farmer have the tendency for increased cassava production when land is not a constraint to them. This finding reflects land as a useful resource in agricultural production such as cassava (Nzeh and Eboh, 2010).

\section{Activities that Contribute to Climate Variability}

The various activities of the small scale cassava farmers that contribute to climate variability are shown in Table 2.

Table 2. Percentage response of farmers according to the perceived activities that contribute to climate variability

\begin{tabular}{lcc}
\hline Farmers' activities & $\begin{array}{c}\text { Frequency* } \\
(\mathbf{n = 1 2 8})\end{array}$ & $\begin{array}{c}\text { Percentage } \\
(\mathbf{\%})\end{array}$ \\
\hline Burning of bush & 113 & 88.28 \\
Intensive agricultural land use & 105 & 82.03 \\
Use of inorganic fertilizers & 77 & 60.16 \\
Use of fossil fuels & 72 & 56.25 \\
Deforestation & 65 & 50.78 \\
Use of herbicides & 54 & 42.19 \\
Use of pesticides & 55 & 42.97 \\
Improper disposal of farm wastes & 46 & 35.94 \\
\hline
\end{tabular}

\section{Source: Field survey, 2017 (Multiple responses)*}

Result in Table 2 tells that the majority of the small scale cassava farmers $(88.28 \%)$ indicated that bush burning contribute to climate variability while $(82.03 \%),(60.16 \%)$, $(56.25 \%)$ and $(50.78 \%)$ indicated that intensive agricultural land use, use of inorganic fertilizers, use of fossil fuels and deforestation contribute also to climate variability, respectively. The implication of this finding is that many of the farming activities in the area contribute to climate change. This finding agrees with the study of Oladipo (2010), who noted that most agricultural activities are the major factors of climate variability.

\section{Level of Awareness of Climate Variability}

The result of mean responses of the level of awareness of climate variability by small scale cassava farmers is shown in Table 3. 
Table 3. Mean responses of the level of awareness of climate variability by small scale cassava farmers

\begin{tabular}{|c|c|c|c|c|}
\hline $\mathbf{S} / \mathbf{N}$ & Climate variability & $\bar{x}$ & SD & Decision \\
\hline 1. & Decreased rainfall days & 2.05 & 0.914 & $\mathrm{~S}$ \\
\hline 2. & Early onset of rainfall and early cessation & 2.08 & 0.929 & S \\
\hline 3. & Absence of frost & 2.02 & 0.816 & $\mathrm{~S}$ \\
\hline 4. & Shorter than normal rainfall & 2.14 & 1.132 & $\mathrm{~S}$ \\
\hline 5. & Low intensity rainfall & 2.02 & 0.872 & $\mathrm{~S}$ \\
\hline 6. & Flash flooding & 2.02 & 1.166 & S \\
\hline 7. & Unusual patterns of precipitation & 2.02 & 0.904 & $\mathrm{~S}$ \\
\hline 8. & High sunshine intensity & 2.01 & 0.886 & $\mathrm{~S}$ \\
\hline 9. & Increase in earth surface temperature & 1.50 & 0.627 & NS \\
\hline 10. & Longer hours of sunshine & 1.95 & 1.173 & NS \\
\hline 11. & Short-lived harmattan & 1.48 & 0.869 & NS \\
\hline 12. & Increase in crop yield & 1.04 & 1.193 & NS \\
\hline 13. & Decrease in crop yield & 1.39 & 0.896 & NS \\
\hline 14. & Loss in soil fertility & 1.55 & 0.954 & NS \\
\hline 15. & Increased erosion & 1.50 & 0.854 & NS \\
\hline 16. & Erratic/unusual rain & 1.55 & 1.175 & NS \\
\hline 17. & Early onset of rain and late cessation & 1.03 & 1.131 & NS \\
\hline 18. & Shorter hours of sunshine & 1.46 & 0.904 & NS \\
\hline 19. & Delay in the onset of rainfall & 1.56 & 1.194 & NS \\
\hline 20. & Above normal rainfall & 1.53 & 0.893 & NS \\
\hline 21. & Below normal rainfall & 1.40 & 0.964 & NS \\
\hline 22. & Longer than normal rainfall & 1.41 & 0.918 & NS \\
\hline 23. & Longer period of dry spell & 1.82 & 1.141 & NS \\
\hline 24. & High intensity rainfall & 1.52 & 0.947 & NS \\
\hline 25. & Increase in rainfall & 1.59 & 1.157 & NS \\
\hline 26. & Erratic/torrential rainfall & 1.48 & 0.930 & NS \\
\hline 27. & Increase rainfall days & 1.26 & 1.170 & NS \\
\hline 28. & Rainstorms & 1.62 & 0.896 & NS \\
\hline 29. & Coastal flooding & 1.48 & 0.957 & NS \\
\hline 30. & Gustiness & 1.09 & 1.191 & NS \\
\hline 31. & Erosion/flooding & 1.61 & 0.796 & NS \\
\hline 32. & Rivers and stream overflowing their banks & 1.41 & 0.910 & NS \\
\hline 33. & High frequency of cloudiness & 1.98 & 1.153 & NS \\
\hline 34. & Unusual flooding & 1.53 & 1.170 & NS \\
\hline 35. & Wet spells & 1.24 & 0.867 & NS \\
\hline 36. & Land slides & 1.08 & 1.201 & NS \\
\hline 37. & Increased in frequency of flooding & 1.55 & 1.160 & NS \\
\hline 38. & Low sunshine intensity & 1.23 & 0.846 & NS \\
\hline 39. & Early onset and early cessation of harmattan & 1.09 & 1.193 & NS \\
\hline 40. & Late onset and late cessation of harmattan & 1.38 & 0.887 & NS \\
\hline 41. & Early onset and late cessation of harmattan & 1.20 & 0.861 & NS \\
\hline 42. & Late onset and early cessation of harmattan & 1.91 & 1.184 & NS \\
\hline 43. & Typhoon wind & 1.11 & 1.205 & NS \\
\hline 44. & Erratic wind & 1.69 & 1.092 & NS \\
\hline 45. & High wind speed & 1.88 & 1.136 & NS \\
\hline 46. & Low wind speed & 1.48 & 0.913 & NS \\
\hline 47. & Low frequency of cloudiness & 1.05 & 1.179 & NS \\
\hline 48. & Low frequency of clement weather & 1.03 & 1.048 & NS \\
\hline 49. & Constant fog & 1.08 & 1.188 & NS \\
\hline 50. & Constant drought & 1.01 & 1.187 & NS \\
\hline 51. & Rising temperature & 1.52 & 0.905 & NS \\
\hline 52. & Presence of frost & 1.14 & 1.202 & NS \\
\hline 53. & Presence of hailstones & 1.11 & 1.199 & NS \\
\hline 54. & Constant waves & 1.08 & 1.164 & NS \\
\hline 55. & High humidity & 1.39 & 0.889 & NS \\
\hline 56. & Low humidity & 1.73 & 1.008 & NS \\
\hline 57. & Presence of unfamiliar diseases & 1.95 & 1.149 & NS \\
\hline 58. & Presence of unfamiliar pests & 1.57 & 0.986 & NS \\
\hline 59. & High incidence of pests & 1.56 & 0.970 & NS \\
\hline 60. & High incidence of diseases & 1.41 & 0.910 & NS \\
\hline
\end{tabular}

Source: Field Survey, 2017 
$\overline{\mathrm{X}}=$ Mean; SD $=$ Standard Deviation; Mean $\geq 2=$ Significant $(\mathrm{S})$; Mean $\leq 2=$ Not significant (NS)

The result shows that the small scale cassava farmers were significantly aware of the following climate variability in the study area: decreased rainfall days $(\overline{\mathrm{X}}=2.05 ; \mathrm{SD}=0.914)$, early onset of rainfall and early cessation $(\overline{\mathrm{X}}=2.08 ; \mathrm{SD}=0.929)$, late onset of rainfall and early cessation $(\overline{\mathrm{X}}=2.02 ; \mathrm{SD}=0.816)$, shorter than normal rainfall $(\overline{\mathrm{X}}=2.14 ; \mathrm{SD}=1.132)$, low intensity rainfall $(\overline{\mathrm{X}}=2.02 ; \mathrm{SD}=0.872)$, flash flooding $(\overline{\mathrm{X}}=2.02 ; \mathrm{SD}=1.166)$, unusual patterns of precipitation $(\overline{\mathrm{X}}=2.02 ; \mathrm{SD}=0.904)$ and high sunshine intensity $(\overline{\mathrm{X}}=2.01 ; \mathrm{SD}=$ 0.886). Also, the farmers indicated that they were not significantly aware of the following climate variability: erratic/unusual rainfall with $(\overline{\mathrm{X}}=1.55$; SD $=0.914)$, longer period of dry spell $(\overline{\mathrm{X}}=1.82 ; \mathrm{SD}=1.132)$, unusual flooding $(\overline{\mathrm{X}}=1.53 ; \mathrm{SD}=0.904)$, longer hour of sunshine $(\overline{\mathrm{X}}=1.95 ; \mathrm{SD}=1.173)$, decrease in crop yield $(\overline{\mathrm{x}}=1.59 ; \mathrm{SD}=0.896)$, loss in soil fertility $(\overline{\mathrm{X}}=1.55 ; \mathrm{SD}=0.954)$, increased erosion $(\overline{\mathrm{x}}=1.50 ; \mathrm{SD}=0.854)$ and rainstorms $(\overline{\mathrm{X}}$ $=1.62 ; \mathrm{SD}=0.896)$. They also indicated awareness of erosion/flooding $(\overline{\mathrm{X}}=1.61 ; \mathrm{SD}=$ 0.796), presence of unfamiliar diseases $(\bar{X}=1.95$; SD $=1.149)$, presence of unfamiliar pest $(\overline{\mathrm{X}}=1.57 ; \mathrm{SD}=0.986)$, high incidence of pests $(\overline{\mathrm{X}}=1.56 ; \mathrm{SD}=0.970)$. However, they were not aware of the following climate variability: short-lived harmattan $(\overline{\mathrm{x}}=1.48 ; \mathrm{SD}=0.869)$, presence of frost $(\overline{\mathrm{X}}=1.14 ; \mathrm{SD}=1.202)$, low wind speed $(\overline{\mathrm{X}}=1.48 ; \mathrm{SD}=0.913)$.

The standard deviations show the variability from their means. By implication, the lower the standard deviation the more the respondents are aware of the climate variability; the higher the standard deviation the lesser the respondents are aware of climate variability. The result tells that the cassava farmers are aware of climate variability. These findings were in line with the result from trend analysis on such climate change variables conducted by Nwaiwu (2014), Ezeano and Albert (2012) and Onubuogu \& Esiobu (2014) who showed that farmers are aware of climate change effect. Also, it supports the findings of FAO (2010) that there has been spatial increase in climatic variability from 1905 to 2010, and this is expected to continue over time. 


\section{Testing of Hypothesis}

The null hypothesis stated that; there is no significant relationship between socio-economic characteristics and production level by the small scale cassava farmers. The data for the hypothesis are presented on Table 4.

Table 4. Multiple linear regressions of the socio-economic characteristics and production level of small scale cassava farmers

\begin{tabular}{lrrrrr}
\hline $\begin{array}{l}\text { Socioeconomic } \\
\text { variables }\end{array}$ & Coefficient & $\begin{array}{c}\text { Standard } \\
\text { error }\end{array}$ & \multicolumn{1}{l}{ Sig. } & $\mathbf{R}^{2}$ & p-value \\
\hline Age & 0.278 & 0.126 & $\mathbf{0 . 0 2 8}$ & 0.176 & 0.048 \\
Sex & -0.226 & 0.242 & 0.351 & & \\
Marital status & 0.154 & 0.170 & 0.363 & & \\
Household size & 0.370 & 0.152 & $\mathbf{0 . 0 1 5}$ & & \\
Education level & 0.199 & 0.154 & 0.195 & & \\
Farming years & 0.428 & 0.183 & $\mathbf{0 . 0 1 9}$ & & \\
Farm size & 0.624 & 0.123 & $\mathbf{0 . 0 4 6}$ & & \\
Labour source & 0.021 & 0.163 & $\mathbf{0 . 0 3 7}$ & & \\
Membership & 0.330 & 0.239 & 0.167 & & \\
organization & 0.334 & 0.226 & 0.164 & & \\
Income & 0.233 & 0.233 & 0.143 & & \\
Yield & & & &
\end{tabular}

Table 4 shows multiple linear regressions of the socio-economic characteristics of small scale cassava farmers and their production level. The R-square value of 0.176 indicates that the socio-economic variables explained $17.6 \%$ variability of cassava production. Of all the socio-economic variables, age (0.028), household size (0.015), farming years $(0.019)$, farm size (0.046) and labour source (0.037) have significant coefficients $(\mathrm{p}<0.05)$. The coefficient value of 0.278 for age indicates that a unit increase in age increases level of cassava production by $0.278 \mathrm{~kg}$. The coefficient value of 0.370 for household size indicates that increase in household size increases level of cassava production by $0.370 \mathrm{~kg}$; that of farming years which is 0.428 indicates that increase in farming experience increases level of cassava production by $0.428 \mathrm{~kg}$; that of farm size which is 0.624 indicates that increase in farm size increases level of cassava production by $0.624 \mathrm{~kg}$ while that of labour source which is 0.021 indicates that increase in labour source increases the level of cassava production by $0.021 \mathrm{~kg}$. Since the p-value is 0.048 , the null hypothesis is rejected and is concluded that there is significant relationship between socio-economic characteristics and production level by the small scale cassava farmers. This means that as the age, household size, farming years, farm size and labour source of small scale cassava farmers in Anambra State increase their propensity to produce cassava also increase. This finding is in agreement with the study of Oladipo (2010) who noted that household size and farm size increases farmers' food production. 


\section{Conclusion}

From the findings of this study, small scale cassava farmers in Anambra State were young, based on the fact that most of them are between 41 and 50 years with mean age of 41.25 . This makes cassava production in the area higher than it can possibly be.

However, considering their educational level, the farmers were aware of climate variability such as increased in rainfall, erratic rainfall, delay in the onset of rainfall, increased rainfall days, increased in earth surface temperature, longer hours of sunshine, rainstorms, presence of unfamiliar diseases and pest, loss in soil fertility and increased erosion. As a result of these, it is concluded that climate variability effects reduces cassava production. The small scale cassava farmers are able to manage the effects of climate variability through indigenous and improved strategies in order to increase cassava production in the state in general.

\section{Recommendations}

Based on the findings of this study, these recommendations are made:

i. Farmers are encouraged to use radio set, television set and internet/social media as source of information.

ii. The small scale cassava farmers should adapt improved agricultural strategies to cope with ever-increasing climate variability.

iii. Proper education on climate variability should be made available to the farmers through environmental experts and extension agencies to curtail various effects of these vagaries of weather on production potentials.

\section{References}

Agbugba, I. K., \& Elijah, S. T. (2017). Yam Production Practices and Climate Change in Cross Rivers State, Nigeria. Delta Agriculturists, 9(2/3), 25-41.

Anyadike, R. N. C. (2009). Climate Change and Sustainable Development in Nigeria: Conceptual and Empirical Issues; Lecture Series, African Institute for Applied Economics, Enugu, 12-28.

Apata, T. G., Samuel, K. D., \& Adeola, A. O. (2009). Analysis of Climate Change Perception and Adaptation among Arable Food Cassava-based crop farmers in South Western Nigeria. Contributed Paper prepared for presentation at the International Association of Agricultural Economists' Conference, Beijing, China. August 16-22, 209.

Elijah, S. T., Osuafor, O. O., \& Anarah, S. E. (2018). Effects of Climate Change on Yam Production in Cross River State, Nigeria. International Journal of Agriculture and Forestry, $8(2), 104-111$.

Ezeano, C. I., \& Albert, C. O. (2012). Climate change, its implication for agricultural and rural development in Nigeria. Journal of Agric and social Research (JASR), 12(1), 8-11.

Ezeano, C. I., Okeke, C. C., \& Gbughemobi, B. O. (2016). Effects of rising temperature and 
wind on productivity of women farmers in anambra east local government of Anambra State Nigeria. International Journal of Agricultural Biosciences, 5(3), 124-127.

Fankhauser, S. (2010). Adaptation to Climate Change. Grantham Research Institute on Climate Change and Centre for Climate Change Economics and Policy, London School of Economics.

Food and Agriculture Organization [FAO] (2000). Two Essays on Climate Change and Agriculture.A Developing Country Perspective.FAO, Rome, Italy. Food and Agriculture Organization. 25-29

Gbetibouo, G. A. (2009). Understanding Farmers' Perceptions and Adaptations to Climate Change and Variability: The Case of the Limpopo Basin, South Africa. IFPRI DiscussionPaper No. 00849. 23-27

Ibekwe, C. C., \& Chidiebere-Mark, N. (2012). Resource Use Efficiency in Cassava Production in South-Eastern Nigeria. Asian Journal of Agricultural Extension, Economics and Sociology, 1(1), 16-21. https://doi.org/10.9734/AJAEES/2012/2028

IFOAM (2007). Organic Agriculture's Role in Countering Climate Change. IFOAM Average Report, Germany.9-13.

Iheke, O. R., \& Oliver-Abali, V. I. (2011). Farm size, climate variability and arable crop production in Abia State, Nigeria. International Journal of Sustainable Agriculture, 3(2), 58-64.

Khanal, R. C. (2009). Climate Change and Organic Agriculture. The Journal of Agriculture and Environment, 10, 100-110. https://doi.org/10.3126/aej.v10i0.2136

Kurukulasuriya, P., \& Mendelsohn, R. (2006). A Ricardian Analysis of the Impact of Climate Change on African Cropland. CEEPA Discussion Paper No. 8. Centre for Environmental Economics and Policy in Africa, University of Pretoria.

https://doi.org/10.1596/1813-9450-4305

Nwaiwu, I. U. (2014). Effects of Climate Change on Labour Use Efficiency and Sustainable Food Crop Production Systems in Southeast Nigeria, Unpublished Ph.D Thesis Submitted to the Postgraduate School, Federal University of Technology, Owerri. 32-56

Nwajiuba, C. U. (2010). Adaptation to Climate Change: Challenges and Opportunities. Lecture Series: Department of Agricultural Economics, Imo State University, Owerri, Nigeria. $34-45$

Nzeh, E. C., \& Eboh, O. R. (2010). Technological Challenges of Climate Change Adaptation in Nigeria: Insights from Enugu State, Enugu, African Technology Policy Studies NetworkPublication. 24-28

Odjugo, P. A. O. (2010). Regional Evidence of Climate Change in Nigeria. Journal of Geography and Regional Planning, 3(6), 7-9.

Ogbo, A. I., \& Onyedinma, A. C. (2012). Climate Change Adaptation In Nigeria: Problems 


\section{Macrothink}

and Prospects Sacha. Journal of Environmental Studies, 2(1), 130-145.

Ohajianya, D. O., \& Osuji, M. N. (2012). Climate Change, Adaptation Measures and the Determinants among Food Crops Farmers in South East Nigeria. Paper presented at the86th Average Conference of the Agricultural Economics Society Warwick University 16-18 April. 34-37.

Okali, D. (2004). Climate Change and Nigeria: A Guide for Policy Makers. 20-25

Oladipo, E. (2010). Towards Enhancing the Adaptive Capacity of Nigeria: A Review of the Country's State of Preparedness for Climate Change Adaptation, Ilorin Nigeria. 23-25

Onubuogu, G. C., Esiobu, N. S., Nwosu, C. S., \& Okereke, C. N. (2014). Resource Use Efficiency of Smallholder Cassava Farmers in Owerri Agricultural zone, Imo State, Nigeria. Scholarly Journal of Agricultural Science, 7(8), 142-152.

Onyeneke, R. U., \& Madukwe, D. K. (2010). Adaptation Measures By Cassava-based Crop Farmers In The Southeast Rainforest Zone Of Nigeria To Climate Change. Science World Journal, 5(1), 114-130. https://doi.org/10.4314/swj.v5i1.61483

World Bank (2008). Agriculture for Development Policy Brief: Adaptation and Mitigation of Climate Change in Agriculture. World Development Report 2008, pp. 3-5.

\section{Copyright Disclaimer}

Copyright for this article is retained by the author(s), with first publication rights granted to the journal.

This is an open-access article distributed under the terms and conditions of the Creative Commons Attribution license (http://creativecommons.org/licenses/by/4.0/). 